\title{
Character Building through Learning Traditional Dance "Tari Piring": An Analysis of Relationship of Dance Style and Social Cultural Community of Pesisir Selatan
}

\author{
Nerosti \\ Sendratasik Education Department \\ Faculty of Languages and Arts \\ Universitas Negeri Padang \\ nerostiadnan@gmail.com
}

\begin{abstract}
This article is part of the research (2017) which aims to analyze the relationship of dance style with socio-culture. This qualitative study using ethnographic methods. The research proves that style of dance has close relationship with social and cultural values. Vocational students who are members of a traditional dance group Bayang Maimbau, felt that learning to dance was learning Minangkabau cultural values. To achieve the ability to dance need to discipline and practice continuously.The research proves the theory by Hughes (2009) that the learning process of traditional dance include four kinds of ethics: (1) discipline; (2) manners and mutual respect; (3) is not arrogant or socializing; (4) consistent and confident. Proved that every move made by the whole body is a skill in coaching ability intellectual character, discipline, creative, and fear of God, shaping the personality, to be responsible, sharing, self-contained and have identity. Found in Piring Dance: (a) Jongkok motion with ten fingers, the meaning educate the polite and respectful nature of human beings as well as uphold God Almighty. (b) The simultaneous motion of one step with a neat floor pattern, keeping the plate not broken, that is to say cultivate a sense of care and socialize. (c) The motion of swinging plates up and down, twisting while maintaining the technique, is the formation of hard, wise, consistent and confident attitude.
\end{abstract}

\section{Keywords- Development of Character, Traditional Dance Lessons, Tari Piring, Identity. Introduction}

\section{DISCUSION}

This article is part of a study (2017) entitled "Model Development of Coastal Minangkabau Dance in Improving the Economy of Traditional Artists in Mandeh Tourism Area" is planned for 3 years, aims: The first year to inventory traditional dances Pesisir Selatan; The second year develops a traditional dance model with a focus on the Pesisir Selatan style; and the third year to organize the management and form of tourism art promotion. Piring dance is one of the dances located in Lubuk Kumpai District of Bayang, taught in traditional art group of Bayang Maimbau, followed by 30 artists. They consist of teenagers aged 1218 Years and people aged 40-68 years. In the process of learning dance teachers always teache how to be polite and respectful, especially to parents, teachers, and friends of age. The learning of these values is not formally taught but through action, as if walking in front of parents should bow down, if shake hands kiss. Likewise, with peer or friends, it is necessary to maintain courtesy to respect each other. Many dance moves that express the local cultural values, also have meaning. Through the research that aims to reveal the relationship of Piring dance style with socio-cultural society, also found the development of characters that can shape the identity of the Pesisir Selatan community.

Based on the growing issues, the research is done in the development of traditional dance area, by taking the object of study Dancing Piring that developed in Nagari Lubuk Kumpai. Lubuk Kumpai is located in Bayang Pesisir Selatan District, a district rich with traditional arts spread in the community. Each nagari has its own art and culture, which shows its diversity and richness of nature and culture. Culture and nature is a great potential to be appreciated and developed for future generations. Thus, the wealth of local culture can grow and grow because it is loaded with symbols that contain local wisdom. This needs to be explored and disseminated to learners as future generations to understand the meaning of each local culture as part of national culture, as well as to teach cultural arts. This is in accordance with the objectives of cultural arts education in schools, especially for the development of student personality from the aesthetic potential that is believed to refine the human mind. The application of the dance lessons has been applied indirectly to the traditional art group of Bayang Maimbau led by the father of Alidas.

\section{RESEARCH METHOD}

The research, designed for 3 years, chose the location of three sub-districts, namely District of IV Jurai, Bayang, and Koto XI Tarusan. These three sub-districts are a buffer zone of Mandeh tourist area. Use qualitative method type using an ethnographic approach. A more focused ethnography on field study and participant observation, which aims to examine the activities of Tari 
Piring in the Society's way of life, to obtain a description of the social and cultural structures of a community and the dance activity of the Dance in the Bayang Maimbau group. Interviews with several informants such as Piring dancers, music dancers, and community leaders to obtain data either directly or indirectly related to the research problem. All data are analyzed by sorting according to the sub-chapters that have been designed.For the first year of giving motivation to artists to maintain the tradition with the force of Coastal force on every development of traditional dance choreography. Therefore, the data required are (1) to get information about the traditional dance types found in the field, (2) the data is identified to be chosen as a model to be developed in terms of choreography. (3) Data were analyzed to determine the outcome of the Coastal dance style.

The approach used is built on a multidisciplinary foundation, which starts from the study of performing arts. Concepts of aesthetics, sociology and anthropology, as well as historical approaches (Hermien, 1998: 11) and sociopolitical. Accumulated to provide answers to the issues raised. Because of this research on the performing arts, the main thing is the aspects of performing arts as texts by connecting the context in which the dance develops. The textual and context relationships are very important in analyzing the dance style which is the problem in this research.

Data were collected using observation, interview and recording methods. Then analyzed descriptively qualitative by describing and analyzing dance style to get model to be developed for second year.

\section{A. Character Building and Traditional Dance}

\section{FINDING AND DISCUSSION}

Character building is an issue that has grown not only in Indonesia but also in neighboring countries, which is closely related to the condition of moral decline among society such as violence, fights between students, ethnic fights, free sex behavior, and increasing corruption, and freedom in communicating in social media that is currently very rife in cyberspace both on facebook, twitter, instagram and so on. This is due to the globalization process, caused by the advance of technological and economic development so as to facilitate communication, information, and transportation, which bring positive impact as well as negative impact for a society (Tilaar, 1999: 3).

Western culture, which tends to promote rationality, influences Eastern countries including Malaysia and Indonesia. The fashion trend of Korean culture can not be avoided through free market or global market such as on-line trading which greatly influences people's lifestyle. As a result the community continues to grow and undergo a transformation process so that it is in a transitional condition or in an atmosphere not there and not here. On the one hand the values of tradition are still strongly inherent in the people, on the other hand the current globalization that comes so strong give a change in social life, thus giving birth to global culture (which) is encompassing the world at the international level (Robertson, 1992: 5 ). As a result, it can make the laxity of cultural values that previously by some people still uphold the values of ancestral traditions and religious spirituality, but ultimately undeniable will be deceived and affected by the global life that has been in sight.

Living conditions in global culture that have an impact on ethics and morals need to be nurtured and directed through education, both formally and non-formally. The phenomenon received serious attention and raised various discourses, both from the government and from the community itself. The field of art both theater and dance need to restore the cultural values that should be preserved and preserved in the younger generation. Cultural values that contain ethics and morals should be in the cultural heritage of art, especially in traditional dance or classical dance even in ethnic dance that developed among the community.

Traditional dance as a part of traditional arts, is an art form that is sourced and rooted in the socio-cultural life of the community, so the people in which the art grows and develops feel to have such art. Processing is based on the taste of the supportive community, which has cultural values inherent in the life of tradition, life view, philosophical approach, ethical and aesthetic sense and cultural patterns contained in it. So the results or art products can be accepted by the community as a legacy transferred from the old generation to the younger generation (Achmad, 1991: 40). Therefore, initially the traditional dance offerings are very closely related to religious activities and customs. It is understood that traditional dance is laden with traditional values, so it has functioned for educational purposes taught for specific purposes in education (Kraus, 1969: 4, Rina, 2012: 21). Thus dance is a subject that has a role in fostering human character, although we know that the main character building in educating human beings is family. But by spending half the time by someone on the bench of education, then the school like no longer a forum for processing knowledge in improving one's intellectual, but also a place of character building (sofft skill or human skill).

Character education can be interpreted as an effort to form a personality through education that results seen in the act of a person in the form of good behavior, honest, responsible, respect for the rights of others, hard work and so forth. Indeed, the character of something potent in man, he will then actual dikala constantly developed, trained through the education process (Lickona in Guskey, 2012: 122). The ultimate hope is the realization of students who have moral integrity that can be reflected in everyday life, whether in interacting with God, with fellow human beings and with the natural environment. Ki Hajar Dewantoro (1937) has long expressed the values of life in learning art is "ngerti-nyger-ngelakoni" (realized, menginsyafi and do), which can be used as a starting point to build character in dance learning (Kuswarsantiyo in Sumaryono, 2013: 161). It implies that Character Education is a form of education and teaching that focuses on the behavior and actions of students in appreciating and implementing the values of character into daily behavior. 
The Government of Indonesia has also established a policy as stipulated in Presidential Instruction (Instruction) of the Republic of Indonesia no. 1 of 2010, contains a refinement of curriculum based on "character education" with active learning methods based on the nation's cultural values (Kuswarsantiyo in Sumaryono, 2013: 160). The Ministry of Education and Culture (2010) formed a team of character education,which can develop the design of character configurations in a psychological and socio-cultural context. The configuration is divided into 4 parts, namely: (1) intelligence (intellectual development); (2) the heart (spiritual and emotional development); (3) sports and kinesthetic (psychic and kinesthetic development) and (4) affective and creative development. The configuration can be illustrated as follows:

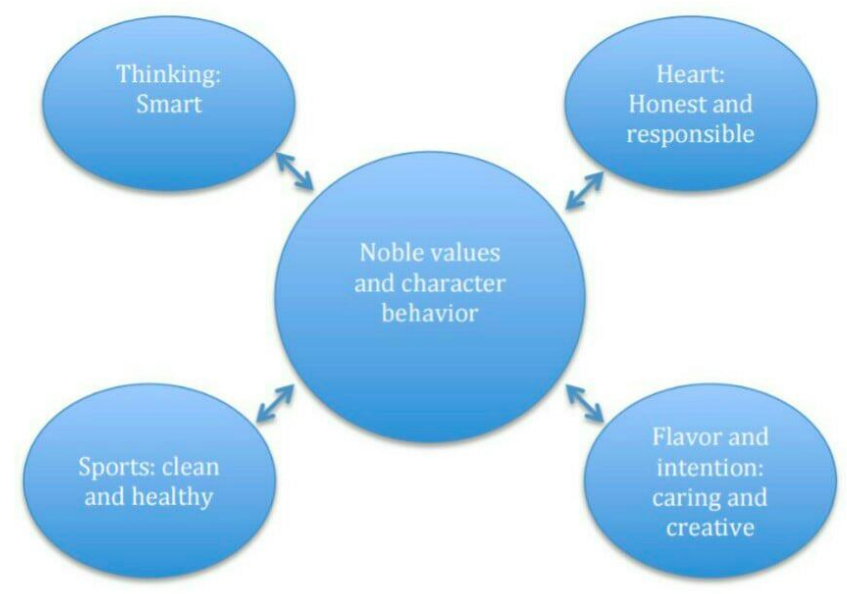

Figure 1: Grand Design Configuration Character, Source: Character Education Team of The Ministry of Education and Culture. RI. 2010. (creativity by Nerosti).

Essentially in the process of learning traditional dance is not only focused on techniques ranging from motion, body fose, continuous motion series and wholeness in dancing alone. But the Learning Outcome is actually transferring about cultural values that are closely related to sofft skills. (4) Team work skills (5) leadership skill (6) entrepreneurial skills (7) professional ethics and (4) skill training (2) Critical thinking and problem solving skills moral (Ministry of Higher Education of Malaysia, 2006: 8).

Dance used as a media in character building will be able to reach 7 criteria sofft skills, will provide many benefits to the students. Not only can dance a dance with a good, ranging from the attitude of motion, body pose and the beauty of the series of motion alone, but because the dance has the meaning of the symbols of motion, then how learners live properly and correctly, it will be able to form mental, both personally and in groups. Students know the culture creatively and express it with joy and happiness. When a dancer moves his entire body with an expressive then because the stage of thinking (if the heart) began to work so he memorized the series of motion for the sake of motion. The ability to express dance well is due to the message conveyed in the dance. Thinking, if the heart, sports and taste and karsa like that tela in the design by the team Kemendikbud will be achieved in the learning of dance. These values can be seen one by one in the movements of dance below.

B. Piring Dance For Means of Character Building of Lubuk Kumpai Youngsters

To find the characters in the Piring Dance in Lubuk Kumpai this can be analyzed on each dance moves Diring as follows:

\begin{tabular}{|l|l|l|}
\hline No & \multicolumn{1}{|c|}{ Description of Movement } \\
\hline 1 & $\begin{array}{l}\text { Pambaoan/looking for position } \\
\text { This movement is an opening act, } \\
\text { dancer in parallel pattern, beginning with } \\
\text { clapping motion, right swing and left } \\
\text { swing, basitenjek in the count of 1-8. } \\
\text { Then the swinging motion is swinging } \\
\text { both hands from right to left on the side } \\
\text { of the body in a count of 1-8. }\end{array}$
\end{tabular}




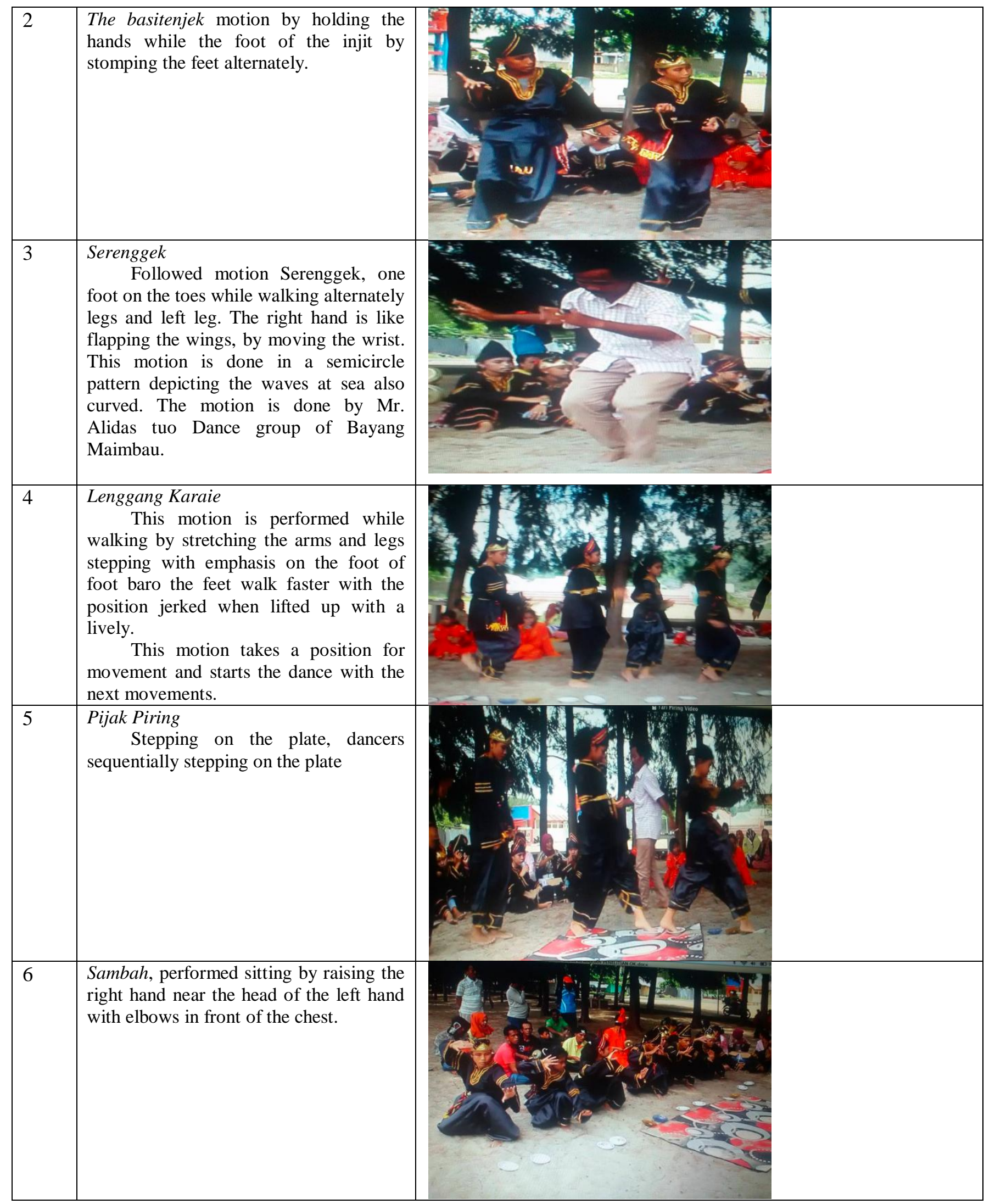




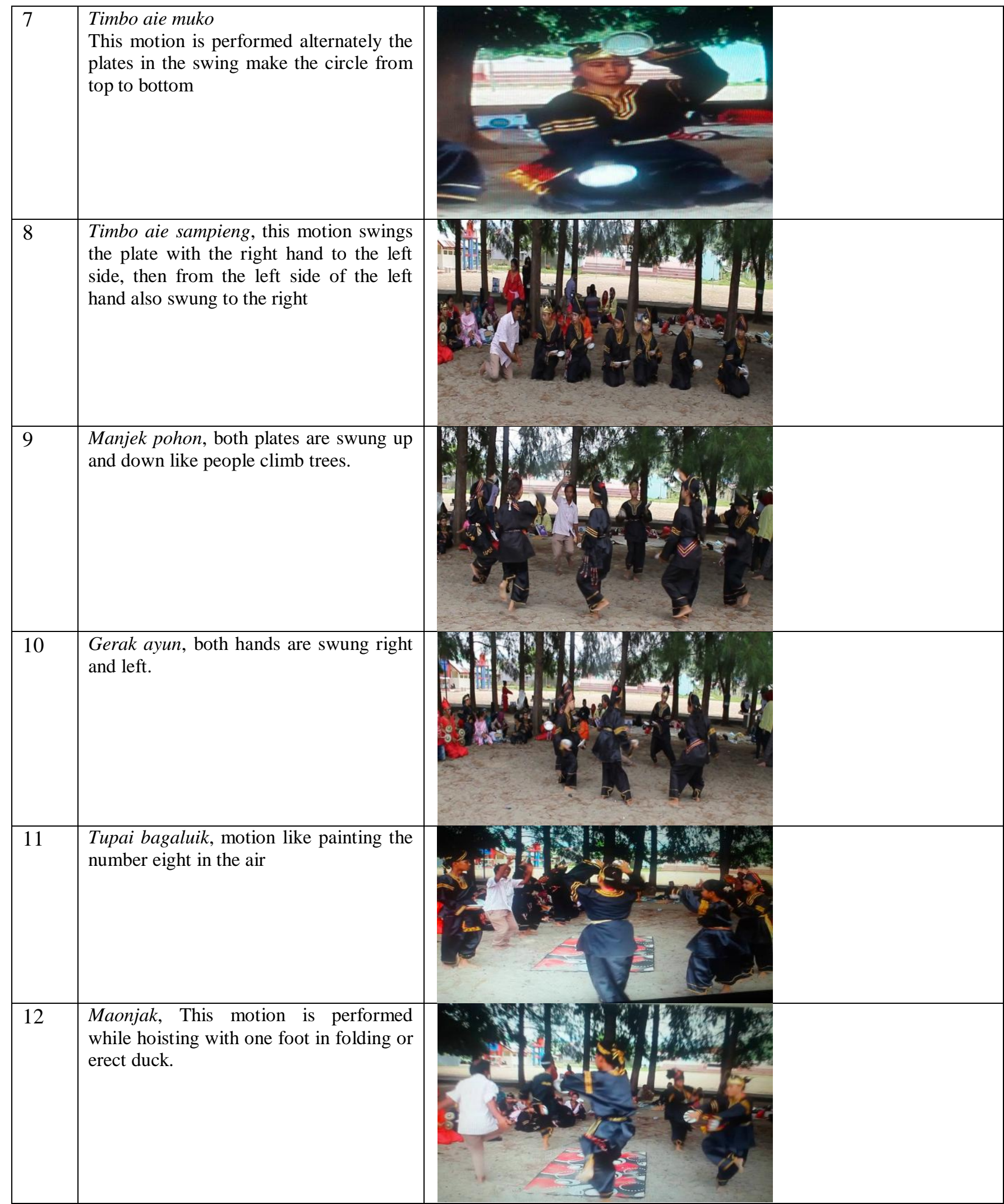




\begin{tabular}{|l|l|l|}
\hline 3 & $\begin{array}{l}\text { Variations of silat, this motion is done } \\
\text { like kicking rewarded with a fixed plate } \\
\text { moved while swaying. }\end{array}$ \\
\hline 14 & $\begin{array}{l}\text { Loncek kekek(sitting position), motion is } \\
\text { done sitting while jumping around like a } \\
\text { frog, hands in swing forward and } \\
\text { backward }\end{array}$ & $\begin{array}{l}\text { Gerak Bagulieng, by rolling over } \\
15\end{array}$ \\
\hline
\end{tabular}

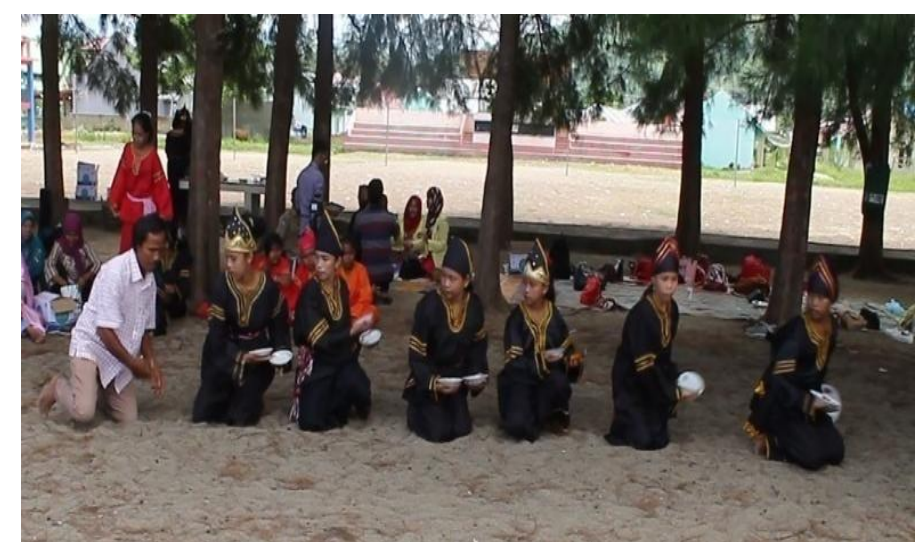

Figure 2. Alidas teaches the timbo aie movement that is interpreteddo not get bored studying.

In the description above motion table can be the relationship of dance style of each motion has values in accordance with the traditions prevailing in the community. Sambah motion is driven by the body in a body posture bent with a sitting position on the dance plate, is a bridge in communicating mutual respect. The most able member of the body to communicate the greeting is the hand of Morris (1977: 24, 27). The purpose of motion performed by the hand will be more clear when accompanied by certain pressures, such as facial expression or head movement. Both hands with fingers in vertical upright position, then attached to the forehead or forehead in front of the face either by bending the face or looking up, or both hands with five fingers upright in front of the chest can symbolize the sign of respect. Similarly, if the hands are clenched or clasped is intended to greet. The movement will be more perfect and more meaningful when followed by a friendly face, with heads bowed and body bent.

The strength of traditional values, the intertwined social relationship between dancers is also strongly reflected in the motion randai. Randai which is a traditional theater of Minangkabau, has elements of dance, vocal, dialogue, and kaba (story), has a distinctive motion, performed in a circular pattern or sphere. Can be seen clearly how beautiful dancers in large numbers sometimes more than 10 people. They move simultaneously to move plates in both hands that unleash the twinkling of the pecan produce a ting ting ting ting in a dynamic tempo, nimbly swinging hands up and down in a circular line in the air, the position of a dancer with a pattern of bersaf, circling simultaneously also move the hand to the side while walking sticky in a circular pattern. The created line imitated a flying eagle with the right wing, a waved, wavy flickering floor pattern. Simultaneously dancers move their hands like painting the number eight with plates in both palms always held so that the plate is facing upwards. Energetic motion is balanced by the curvature of the hands, body bent, all the limbs mutually balance for the plate does not break. For each 
movement shift then followed by obedience and synchronized by the dancers deeply reflects the discipline, mutual tolerance, let alone the distinctive sound of dish plays sound harmonic generated by the ring of the dancer ring that chimes onto the plate they hold. Sometimes a dancer chants ta with full of enchantment and energetic. The movement is so unique composed with dynamic, lively movement, swinging, with a vibrant motion pattern dominated by curved patterns but still energetic. The endurance of the $k u d a-k u d a$ in every agile foot move moves in place and the strength of the arms on the basis of right strength based on the pencak. The movement based on silat is a basic movement in the form of standby, endurance, agility as a self-care for boys. Movement of Tari Piring are dynamic can not be done without through exercises that need discipline, a sense of togetherness to realize the beauty of a very exciting motion. Their movement begins with splinting by arranging a finger, ending with a sitting first to bring both palms, then form a suduang leaf motion which they call pambaoan motion is to start an ethical way. These movements have taught attitudes (1) discipline; (2) courtesy and respect; (3) not being arrogant or socializing; (4) consistent and confident (Hughes, 2009: 162-170).

The simultaneous motion performed by dancers in traditional dance, not only in the form of greetings of respect or beauty alone, but the role or status of the dancers that the importance of social ethics in society (Hermien, 2006: 11). Interwoven relationship between one dancer with other dancers describe the relationships of people who need each other as well as understood as the section of community life is very beautiful. Habit in the exchange of motion Piring Dance using code or shouting cries Up by a leader in a group of dancers, which is then followed aba-alanya by all dancers without exception. Without following the cue, the clash of plates and inevitability of motion can not be avoided will occur plates fall and break. So the beauty of Piring dance that favor the composition of the motion with the power swing plate will not be enjoyed by dancers and spectators.

The good relationship between command and its members in Piring dance when performing velocity and togetherness in every movement, it is very beautiful also apply in real life. Such a thing put forward by Royce (1977: 136): Dance is not only concerned with the actors and the audience, but relates to the social-cultural aspects ..., the overall traits that determine the pattern in the dance develop through imitation and interaction among the members of the community, thus developing an institutional marking of an identity. Each motion pattern is called style, and the force is made up of symbols and forms based on the values orientation embraced, believed, and internalized within the members of the community.

Learning process that communicates messages or values can also be done when a series of motion will be demonstrated by a dance teacher. Another example is one of motion in the Piring dance is a series of motion timbo aie, motion bacamin with motion picture: right hand is swayed to the side in a semicircle so right in front of the face of the plate facing the dancer's face as if mirrored, the motion rewarded by hand kri with perform the same motion, in which the essence of the mirror. When viewed at a glance the motion is as if the mirror in the context of preening or fixing the face is beautiful or not. In fact, the mirrored movement has a deep meaning as it goes in the old "Self-corporeal" adage, which means that one should pay attention to oneself first before being noticed by others, good or bad. In other words, everyone needs to be introspective in order to obtain harmony in the community. In this case, the adat Minangkabau adage says bajalan peliharolah legs, bakato peliharolah tongue (careful in walking, so see, so as not to hurt or feelings of others). Opinions than traditional dance figures can also be referred to the proverbial book petitih Minangkabau (Hakimy, 1991: 38). Motion after movement taught by dance teacher patiently is the process of character formation of the teacher to his students.

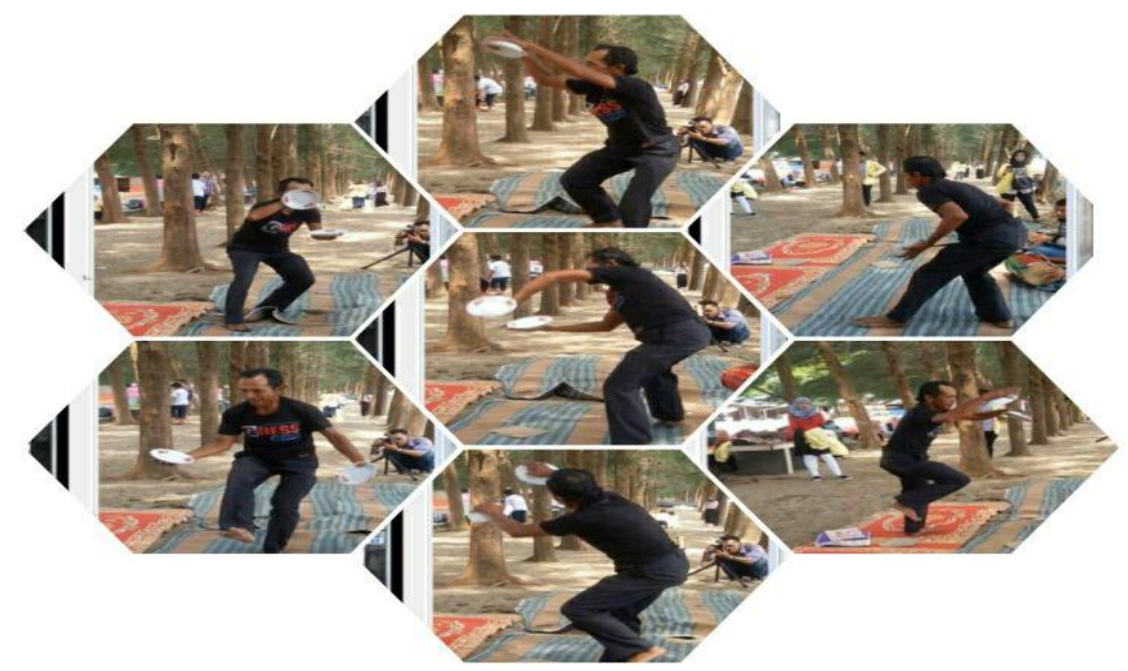

Figure 3. The energetic style of Piring dance is typical of Peisir Selatan Piring dance.

(Documen of Nerosti, 2017) 


\section{CONCLUSION AND SUGGESTION}

Based on the above description, it can be concluded the following:

1) Character development can be done through traditional dance learning for it should be cultural products oriented to the mind, ethics and morals of human beings in accordance with the symbols of dance movement which contains the content of cultural values that should be upheld, passed on continuously to the younger generation while the dance lessons run well in formal and non-formal institutions.

2) The Meaning of motion Tari Piring is:(a) Greetings respect to the guests, (b) Jongkok motion with ten fingers, the meaning educate the polite and respectful nature of human beings as well as uphold God Almighty. (c) The simultaneous motion of one step with a neat floor pattern, keeping the plate not broken, that is to say cultivate a sense of care and socialize.(d) The motion of swinging plates up and down, twisting while maintaining the technique, is the formation of hard, wise, consistent and confident attitude.

3) Implementation of Character Education through traditional dance learning is one of the efforts to be used as the basis for the guidance of the character of the nation's children, therefore the social-cultural environment where the traditional dance is located is Bayang Pesisir Selatan is a conducive source for the students, both from the side the family environment, the school, and especially the cultured community as a determinant in transferring these values and a strong base for the character development of the nation, therefore the development of traditional art should be fully supported by the government in order to maintain regional identity.

4) Traditional arts groups are centers of education and centers of cultural development institutions that once gus is also the center of study, and the development of the sciences to achieve the progress of human civilization. For the traditional art activists need to be fully supported by the government in order to maintain regional identity and build the character of the nation, especially the younger generation Pesisir Selatan.

5) Should the art teacher in running dance lessons remain firmly achieve soft skills in accordance with the theory of Bloom (1956), namely: (1) Intelectual empowerment or cognitive domain (cognitive domain). (2) the practice of values in the formation of attitudes and morals or affective domains, and (3) skills training or physical skills (pcychomotor domain) (Guskey, 2012: 143). The three domains are also in accordance with the Grand Design Configuration Character compiled by Kemendikbud namely: (1) the level of intelligence / intellectuals called "thought through", (2) honesty and sense of responsibility or "if the heart", (3) cleanliness and health or "sports," and (4) caring and creativity or "taste and karsa", which are steps to realize "noble values and character traits".

\section{References}

Anis MD Nor, Mohd Ed. Zapin Melayu di Nusantara. Johor: Yayasan Warisan Johor. 2000.

Bloom, B.S. (Ed.). Engelhart, M.D., Furst, E.J., Hill, W.H., Krathwohl, D.R. Taxonomy of Educational Objectives, Handbook: The Cognitive Domain. New York: David McKay Co Inc. 2006.

Caturwati, Endang. "Pendidikan Seni dan Pembentukan Karakter" dalam Sumaryono Ed. Dialektika Seni Dalam Budaya Masyarakat. Persembahan 80 Tahun Prof. Dr. RM Soedarsono. Yogyakarta: Badan penebit ISI Yogyakarta. 2013.

Desmond Morris, Manwatching: A Field Guide to Human Behavior. New York: Harry N Abraham, Inc. 1977.

Guskey, R Thomas. Benjamin S Bloom: Portraits of an Education. United Kingdom: Published by Rowman \& Littlefield Education. 2012.

Borg, W.R. \& Gall, M.D. Educational Research: An Introduction. New York and London: Longman. 1977.

Hakimy, Idrus. 1000 pepatah, petitih, mamang, bidal, pantun, gurindam : bidang sosial budaya, ekonomi, politik, hukum, hankam, agama di Minangkabau. Bandung: Rosda. 1991

Hughes, Felicia. Komunitas yang mewujud: tradisi tari dan perubahan di Jawa. Yogyakarta: Gadjah Mada University Press. 2009.

Imran, Mohd. Nefi. Tari Melayu Malaysia: Satu Kajian berdasarkan Festival Tari Kebangsaan.Kuala Lumpur: ASWARA. 2011.

Kraus, Richard G. History of Dance in Art and Education. New Jersey: Prentice-Hall. 1969.

Kusmayati, A.M Hermien (2006) “Aspek Estetika Dalam Bingkai Seni Pertunjukan” Pidato Pengukuhan Jabatan Guru Besar pada Fakultas Seni Pertunjukan Institut Seni Indonesia Yogyakarta, 25 Maret 2006.

Nerosti, "Jati Diri Dalam Tari: Folkdance Mengikut Citarasa Semasa/ Kontemporari” Makalah disampaikan pada bengkel Kemahiran Seni (Koreografi) Anjuran Istana Budaya di Cherating Beach Resort Kuantan Pahang, Malaysia.1 Desember 2011 ,

Rina Martiara. Nilai dan NormaBudaya Lampung Dalam Sudut Pandang Strukturalisme. Yogyakarta: Kanisius. 2012.

Robertson, Roland. Globalisastion: Social Theory and Global Culture. University of Aberdeen, Scotland. Uninted Kingdom.: SAGE Publication. 1992 